\section{SAAAA \\ JOURNAL}

Open Access
Journal of Archaeology and Fine Arts in Southeast

Asia

Published by the SEAMEO Regional Centre for Archaeology and Fine Arts (SPAFA)

\title{
Preliminary Results of Archaeological Investigation in Cagsawa Ruins in Albay, Philippines: Sacred Spaces Archaeology
}

Angel Sarmiento Recto

Bulacan State University

profangelrecto@yahoo.com

Evangeline Ramos Recto

Archaeological Studies Program

University of the Philippines

Reynaldo Ramos Avellana

Archaeological Studies Program

University of the Philippines

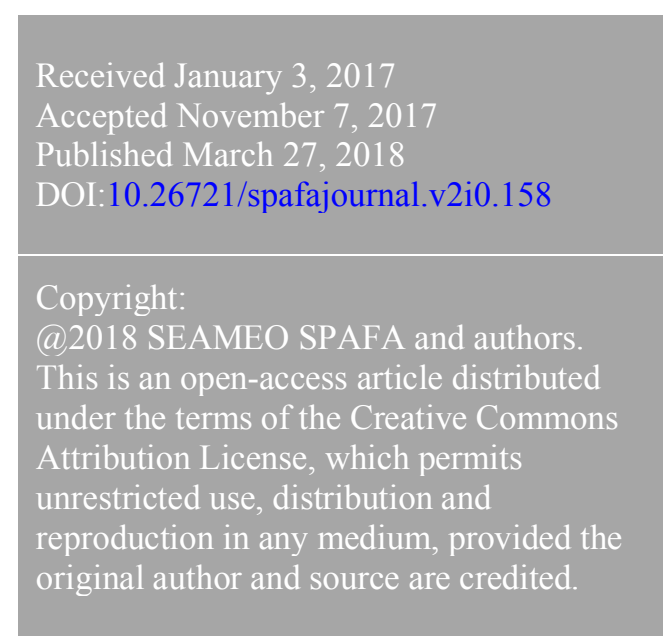

\section{Abstract}

The Cagsawa Ruins is a popular name of the former Franciscan missionary complex which was demolished and rebuilt - particularly the church and convent - in 1724 by Fray Francisco Blanco, OFM, to make it bigger and stronger. The place was devastated by a violent volcanic eruption on 1 February 1814, when thousands of people in the nearby towns of Camalig, Daraga and Budiao were killed by pyroclastic flows and lahar. Since the 1814 eruption of Mount Mayon, the Cagsawa Ruins have been left undisturbed. No archaeological activities had been made in the area. The entire plan and blueprint of the Franciscan missionary complex remained unknown to many after the devastating eruption of Mayon. Some parts of the stone structures are still visible, while others are submerged. This paper will share the preliminary results of archaeological investigation at the Cagsawa Ruins.

Keywords: Cagsawa Ruins, Alcantarine Franciscans, missionary complex, Albay, Sacred Spaces Archaeology 


\section{Introduction}

The Cagsawa Ruins, located in the town of Daraga in the province of Albay, the Philippines (Fig. 1), is a popular name of the former Franciscan missionary complex which was demolished and rebuilt - particularly the church and convent - in 1724 by Fray Francisco Blanco, OFM, to make it bigger and stronger ${ }^{1}$. The place was devastated by a violent volcanic eruption in on February 1814 and was buried by lahar and pyroclastic materials. Also affected were houses and churches in the towns of Budiao, Camalig, Daraga and Guinobatan, where thousands of people died, and so did livestock. It has been claimed that 1,200 people were killed and covered by lahar and volcanic ash. ${ }^{2}$ From 1814 to today, the shattered missionary complex of the Franciscans in Cagsawa has been abandoned as a regular place for worship and other religious activities. It has now become a tourist destination in the region. It is important to know that the early friars who evangelized the Bicol Region belonged to the Alcantarine group of Franciscan Separatist, headed by San Pedro Bautista of the Stricter Observance, also known as the Discalced or Barefooted Friars.

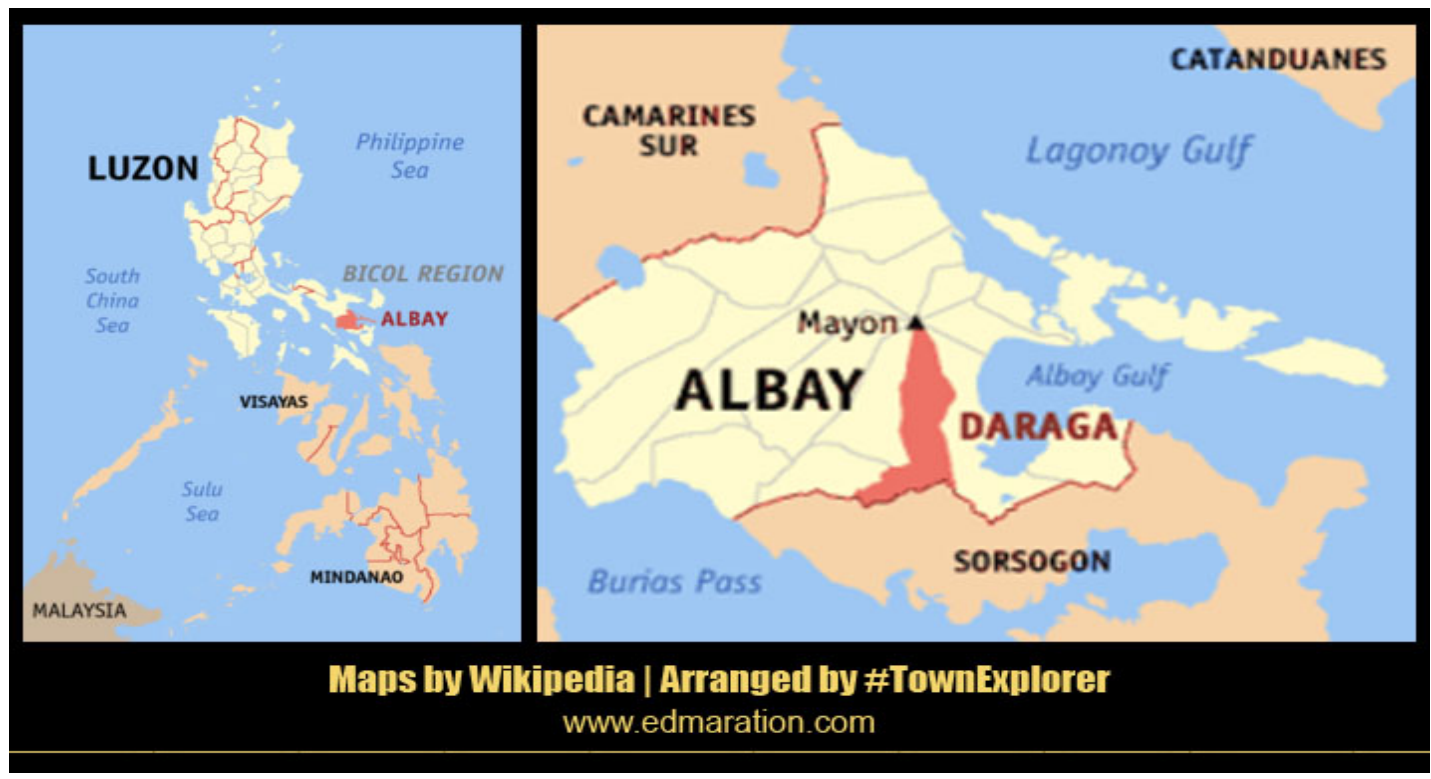

Fig. 1. Map of the Province of Albay. Source: Ed Maration.

Several years after, the ruins in Cagsawa became famous because of its panoramic view, where the background of which is the majestic vista of Mount Mayon with its perfect cone. Multitudes of tourists from different parts of the globe visit the ruins and enjoy the scenery of the volcano with its surrounding nature and exciting All-

Terrain Vehicles (ATV) activities. With all these beneficial activities on the part of the tourists, guests and visitors of the place, the Local Government Units (LGU) of the municipality of Albay and the diocese of Legazpi set plans to develop and refurbish the site for tourism and pilgrimage purposes.

\footnotetext{
${ }^{1}$ Huerta 1865: 270; Platero 1880: 388.

${ }^{2}$ Sanger 1905: 240; Villamor 1920: 84.
} 
For more than two hundred years after the violent eruption of Mount Mayon, the ruins in Cagsawa remain silent and mysterious of their past events and activities. There have been no intentions on the part of the Franciscan Order, diocese of Legazpi and even the Local Government Units (LGU) of the municipality of Daraga, Albay regarding the future direction of the area. Such tranquility shook my archaeological interest to investigate the unexplored ruins as a significant landmark and historic marker of the 1814 eruption of Mount Mayon, where allegedly 1,200 people were trapped and buried inside the church. Since then, there has been no attempt to conduct archaeological investigation to the ruins. The objective of this archaeological exploration is to identify the Franciscan missionary complex and distinguish every existing stone structure; construct a map to ascertain the distance of every stone structure from each other; and determine the construction technology in building the stone walls and posts.

The attempt of exploring the ruins in Cagsawa focuses on the Archaeology of Sacred Spaces because the area was a religious complex where consecrated people and baptized individuals to the Catholic faith worked and lived for a long period of time. The archaeology of sacred spaces is new in Philippine archaeology in view of the fact that the discipline originated in Rome, Italy, in 1852 with the primary objective of taking care of ancient sacred cemeteries and looking after their preservation, further explorations, research and study. ${ }^{3}$ Pope Pius IX created a particular Pontificia Commissione de Archeologia Sacra for that purpose. As a matter of fact, the primary intention of the first archaeological excavations in ancient Rome that took place at the end of the $7^{\text {th }}$ century was to gather the remains of the early Christian saints and translocate the sacred objects to the subway cemeteries, known as the catacombs, which were safe and protected from the enemies' sacrileges and desecrations. ${ }^{4}$ The Catholic Church highly regards places of worship for the living and a 'valley of repose' for the departed brothers and sisters as holy and sacred spaces that deserve veneration and respect. The ruins in Cagsawa in Albay have similar significance of being a sacred place for worship and entombment of the departed adjacent to it.

It is visible and tangible until today that the ruins in Cagsawa insinuate two worlds inside the walls (Intra-muros) of the complex: the spaces of the sacred and profane. In most pueblos or towns in the Philippines during the Spanish regime, ecclesiastical and gubernatorial affairs shared the same space in one entire complex, fortified by stone walls and fortresses against the enemies and intruders. ${ }^{5}$ It implies that the affairs of the sacred and profane complemented each other as far as evangelization is concerned (Fig. 2)

\footnotetext{
${ }^{3}$ De Rossi 1864: 2-9; Annuario Pontifico 2001: 1621-1622.

${ }^{4}$ Lanciano 1902: 3; Parker 1877: 1-3; Maitland 1847: 42.

${ }^{5}$ Lib. I. Tit. III.
} 


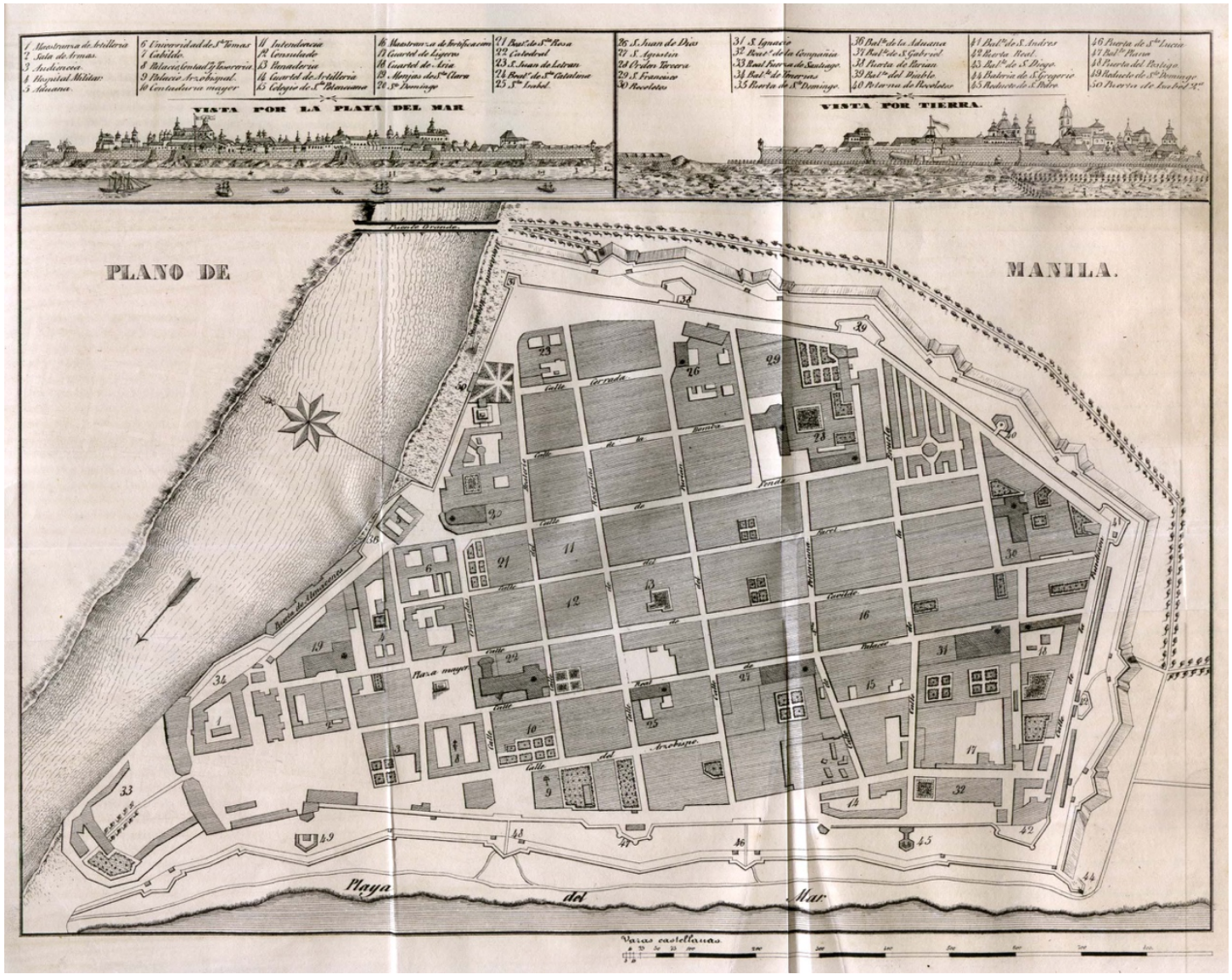

Fig. 2 Intra-muros Manila during the Spanish regime where the sacred and profane spaces shared in the same area. Source: Buzeta 1850.

During the Spanish colonization of the Philippines, there was no exact definition of sacred spaces in the Laws of the Indies. However, what is clearly stated in the promulgated laws of the Kings of Spain were Lugares Sagrados or sacred places, namely the church altar where the chalice and paten are placed, and the belfry where the bell is hung. ${ }^{6}$ Likewise, the Constitution of the Sacred Liturgy mandated the local ordinaries or the diocesan bishops that in every construction of the church, an altar should be worthy and well planned, noble and safe for the Eucharistic tabernacle; there should be a dignified and suitable space for baptistery; and sacred images should be in proper and respective places including sacred arts and vestments. ${ }^{7}$ It entails, therefore, that the entire edifice is a sacred space for it is destined for sacred liturgy and worship. On the other hand, the New Code of Canon Law of the Latin Rite defines sacred places as designated areas for divine worship or for the burial of the faithful by a dedication or a blessing which the liturgical books prescribe for this purpose, namely church, oratory, altar, shrine and cemetery. Thus, sacred places as stated by the ecclesiastical laws are designated specific areas consecrated and blessed by the local ordinary for a particular purpose. The church in Cagsawa - though dilapidated - is still sacred and a holy place because the bishop of the place affirmed

${ }^{6}$ Lib. I. Tit. III; Yengoyan 2006: 353

${ }^{7}$ Flannery 1975: 35-36; Jonova 2017: 195. 
the sacredness of the space. ${ }^{8}$ Consequently, any religious activity, particularly Holy Mass, can be celebrated in the ruins anytime the bishop allows it.

Every sacred space is a manifestation of the divine where people experience awe and wonder and deep encounter of sanctity of the place. ${ }^{9}$ Sacred places to most religions are real places on ground. The famous Mount Banahaw in the province of Quezon is greatly considered as a sacred mountain by believers and pilgrims ${ }^{10}$ because nature speaks forcefully and the people learn how to listen to the wise and persuasive voice of nature. Mount Banahaw is a spiritual centre and a mysterious sacred space for it attracts mystics and those who in one way or another are searching for God or contact with the divine (Fig. 3). The place is a melting pot for folk animism and Catholicism where pilgrims freely express their religious sentiments with nature through sacred trees, caves, rocks, rivers and waterfalls which the faithful believe are guarded and protected by anitos and diwatas, despite the fact that each particular station (like peak or cave) has been named after a Catholic saint or patron (like Balon ni Santong Jacob or St. Jacob's Well). The believers and pilgrims recognize that sacred spaces are endowed with divine meaning that fill their spiritual emptiness and transform their lives to become better persons.

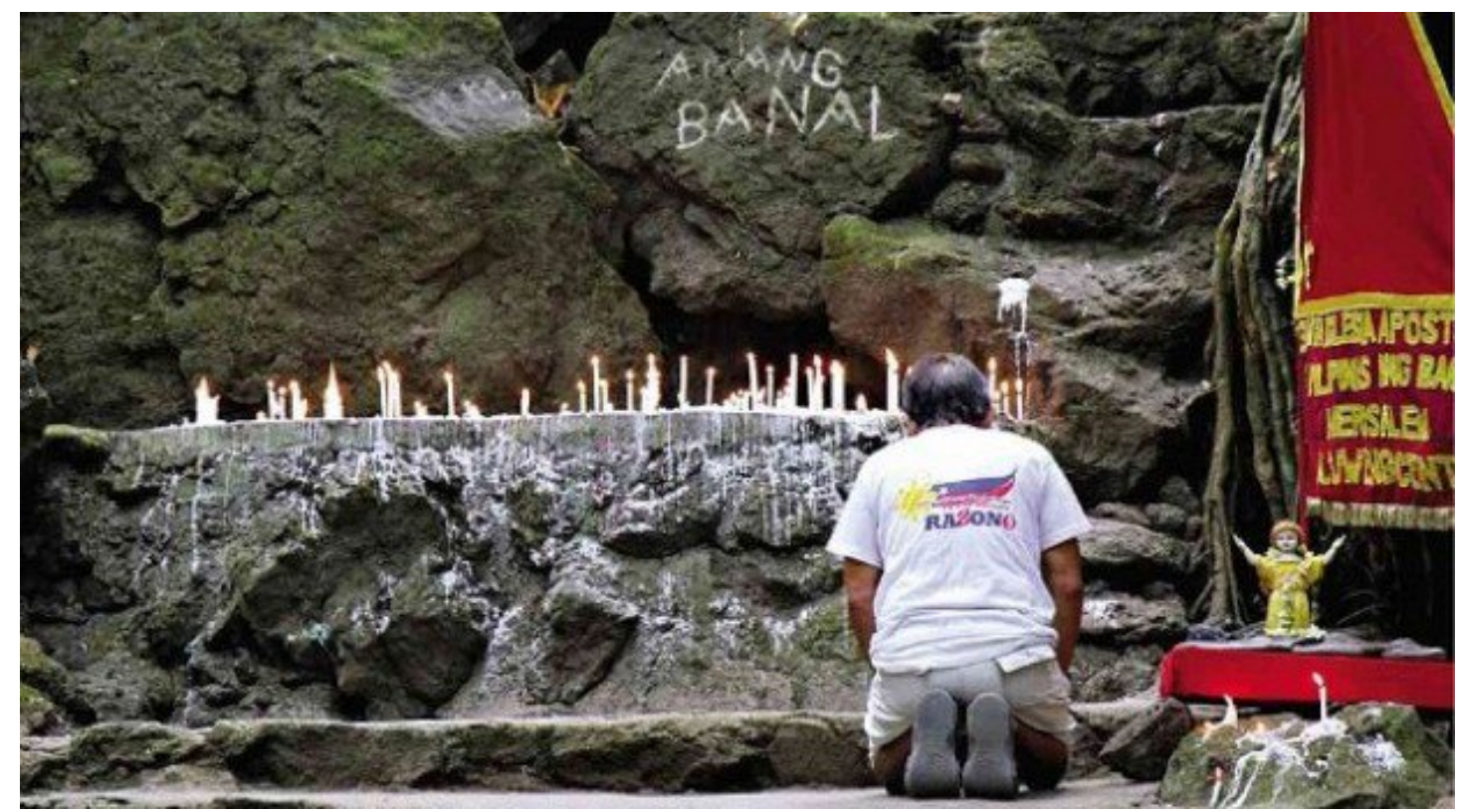

Fig. 3 A man is praying in front of one of the pwestos or sacred rock in Mount Banahaw. (www.notey.com)

Some sacred spaces are chosen because they are associated with people who have some particular religious credibility. ${ }^{11}$ For instance, the Apostolic Catholic Church in Sacrifice Valley in Hermosa, Bataan, founded by Maria Virginia Peñaflor Leonzon, and the Kamay ni Hesus (Hand of Jesus) Healing Church in Lucban, Quezon

\footnotetext{
${ }^{8}$ Can. 1213.

${ }^{9}$ Eliade 1956: 21; Isaac 1964: 29.

${ }^{10}$ Gorospe 1992: 10-16.

${ }^{11}$ Park 1994: 252.
} 
province, founded by Rev. Fr. Joseph Ayala Faller, are considered sacred places where pilgrims come and congregate to offer prayers and attend healing masses and ceremonies (Fig. 4). Even faith healers and other religious sects frequent the place because they believe in the power that the mountains give them. In other words, sacred space can be defined as a significant social structure that reflects the symbols, beliefs and traditions of each religion in a tangible and visible manner: The holy or the transcendent materialized in the sacred space by ritual acts and symbols. ${ }^{12}$ Holy places serve as the mediator for sacred experiences of an individual or group of individuals to the divine and the ontological link and manifestation between the transcendental world in the immanent world of the believers.

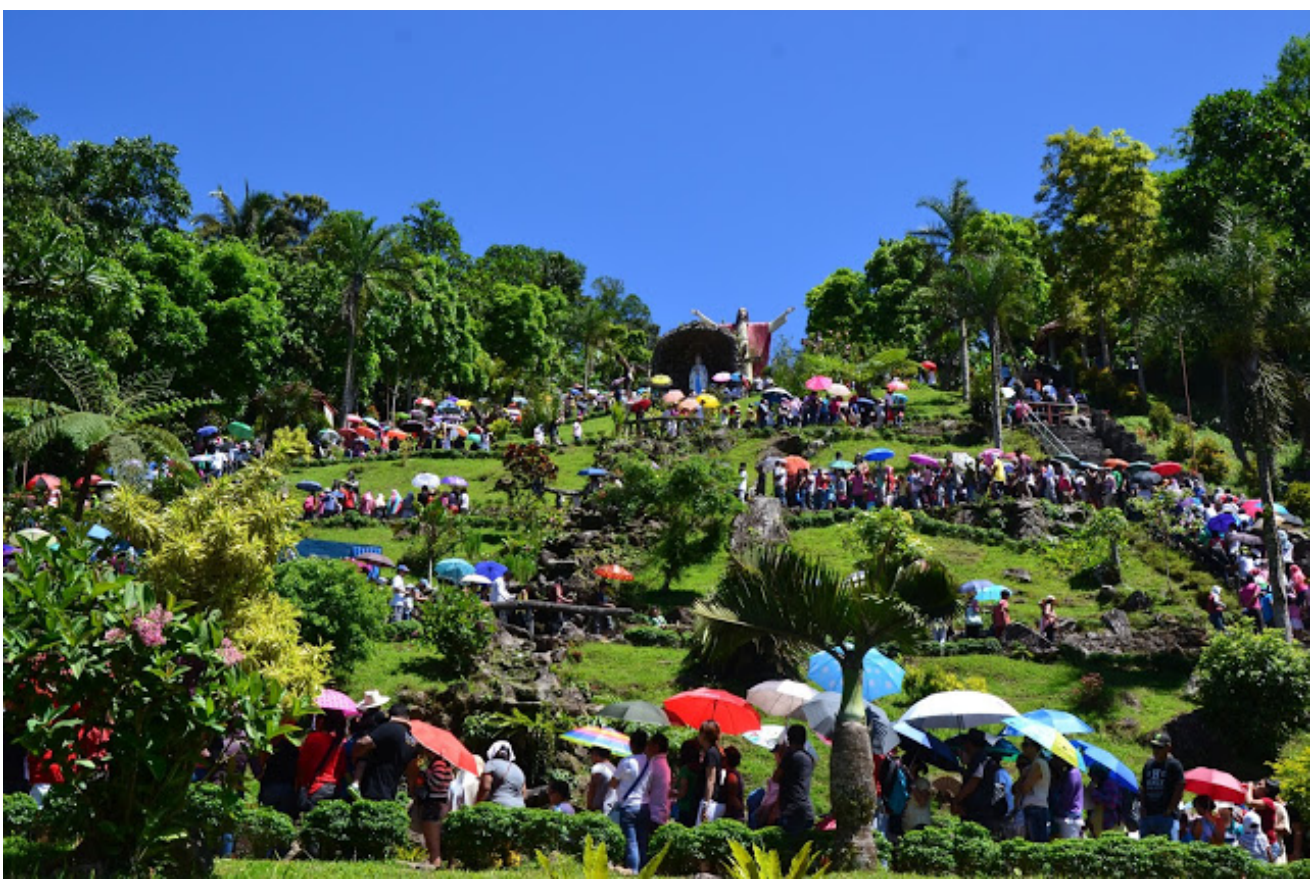

Fig. 4 Kamay ni Hesus Healing Center in Lucban, Quezon. Source: Neil Alvin Nicerio.

Sacred spaces are pilgrim places where devotees undertake a journey to a particular shrine as an act of religious devotion. Such journey involves large numbers of people who travel long distances by a variety of means for specific religious festivals. During the month of May, thousands of pilgrims visit the shrine of Our Lady of Good Voyage in Antipolo, Rizal; Our Lady of the Most Holy Rosary in Manaoag, Pangasinan; Our Lady of Caysasay in Taal, Batangas; and other shrines dedicated to Mary, the Mother of Jesus. People coming from different walks of life spend time in these sacred places to ask for help, guidance and healing from the divine mother and at the same time they give thanks for all the blessings they have received. Similarly, on every 1 February in the ruins in Cagsawa, pilgrims flock to this sacred area to offer prayers and participate in the Holy Mass commemorating the 1814 tragedy of fellow Albayanos.

During the liturgical celebration at the ruins of Cagsawa, the nave (where the faithful are gathered) and the altar (where the celebrant priest presides) are sacred spaces that

\footnotetext{
12 Norman Habel 1993: 33.
} 
connect and bridge them to the divinity. ${ }^{13}$ It happens in the same manner when the unleavened bread (host) and wine are blessed and consecrated by the celebrant priest during the Mass and become the body and blood of Christ. This metaphysical transubstantiation signifies that the material world has emerged to the divinity. Thus the non-sacred materials become holy through the blessing and consecration of the divine representative.

The annual religious celebration in Cagsawa can also have significant impacts on tourism promotion that could affect the local economies. The Local Government Units (LGU) in collaboration with the diocese of Legazpi can develop more souvenir shops, transient or pension houses nearby and facilities for overnight accommodation though seasonal and short-lasting. This archaeological project in Cagsawa is a great opportunity for the province of Albay because it will attract thousands of visitors from all over the world that could strengthen the economies and job opportunities to the Albayanos.

\section{The Province of Albay}

The province of Albay, which was once called Tierra de Ibalon ${ }^{14}$, is located in the southern part of Luzon Island and is bordered by the provinces of Camarines Sur to the north and Sorsogon to the south. To the northwest lies the Lagonoy Gulf leading to the Philippine Sea and to the southwest is Burias Pass. The coordinates of the province is $13^{\circ} 14^{\prime} \mathrm{N}$ latitude and $123^{\circ} 38^{\prime} \mathrm{E}$ longitude.

The word Ibalon is derived from the Bicol term balon which means "provision", "abundance" or "plenty". Adding the $I$, it implies there is "provision", "abundance" or "plenty". In later times, the region was called "Bicol" after the name of the river that tortuously meanders like a huge serpent through the province of Albay and Camarines Sur. ${ }^{15}$ The word "Bicol" is derived from the term Bico, which means "twisted", that described the river's slither-like course towards the Pacific Ocean outlet. ${ }^{16}$

Evident on the surface of the Bicol Peninsula are several fissures initiating the formation of a chain of volcanoes: Mount Labo in Camarines Norte; Mounts Isarog and Iriga in Camarines Sur; Mayon Volcano, Mounts Malinao and Masaraga in Albay; and Mounts Bacon and Bulusan in Sorsogon. There are geothermal fields in Tiwi and Manito-Bacon, Sorsogon, where the rising of magma - instead of being vertically ejected - is funnelled into a reservoir of ground water which is turned into steam. The reservoir rocks consist of andesitic lavas and flow breccias of Mount Malinao and the underlying Miocene-Pliocene Polangui Volcano. The reservoir rocks thicken from the east to west across the field as basement rocks deepen toward the volcano. Basement rocks below the reservoir are metasediments overlain by about 600 metres of intercalated mudstone, limestone and volcaniclastic rock. The reservoir

\footnotetext{
${ }^{13}$ Meskell 2008: 47; Flannery 1975: 34.

${ }^{14}$ Castaño 1895: 3; Huerta 1865: 254; Buzeta 1850: 280; Crawfurd 1856: 8.

${ }^{15}$ Buzeta 1850: 468.

16 Reyes 1992: 103.
} 
rocks are altered to a propylitic mineral assemblage that formed by the interaction with hot geothermal fluids. ${ }^{17}$

Among the active volcanoes in the province of Albay, Mount Mayon is very famous, well known and recognized by many people because of its perfect cone. According to the observation and survey of the Spanish Captain Don Antonio Siguenza, the volcano stands at an elevation of 1,682 Spanish feet (468.66 metres) from the crater to the base which was nearly at the level of the sea. Such measurement differs from the barometrical reading of Jagor in which the height of the summit was 2,374 metres $\left(8,559\right.$ Spanish feet) above sea level. ${ }^{18}$ Currently, the height of Mount Mayon's apex is 2,462 metres ( $8,077 \mathrm{feet})$ above sea level. The first eruption of Mount Mayon took place on 23 October 1766 which, in a few hours, was able to devastate the town of Malinao and greatly damage and ruin the towns of Albay, Cagsawa, Camalig, Budiao, Guinobatan and Ligao. ${ }^{19}$

In 1569 the missionary friars of the Order of Saint Augustine (OSA), also known as the Calced Friars, first entered the Bicol Region from the islands of Masbate, Leyte, Samar and Burias. Fray Alonzo Jimenez, OSA, and Fray Juan de Orta, OSA, were noted concerning evangelization and conversion of the natives in Camarines. ${ }^{20}$

In 1575, the two Augustinians were recalled from their mission outposts. After they left, there is no known historical records as to who replaced them. In 1578, the Alcantarine Franciscan missionaries, also known as the Discalced Friars, who reached Camarines were Fray Bartolome Ruis, OFM, and Fray Pablo de Jesus, OFM. They were the ones who formally commenced the evangelization of the natives of Camarines. In the same year, the two friars immediately started the foundation of the missions of Naga, Nabua, Libon, Quipayo and Minalabag. ${ }^{21}$ In the early days of Bicol evangelization, most of the mission churches were simply built in bamboo-nipa and wooden structures. The construction of stone or brick churches began much later. The only stone or brick churches erected at the end of the 1500s were those of Naga (1595), Quipayo (1616), Libon (1578), Polangui (1583), Oas (1585), Camalig (1575) and Cagsawa (1587). The greater part of the stone and brick churches in Bicol were built in the second half of the $17^{\text {th }}$ and $18^{\text {th }}$ centuries.

\section{Franciscan Evangelization in Cagsawa}

The name Cagsawa is derived from the combination of two Bicol words: cag, which means "of", and sawa, which is equivalent to "python", a species of Philippine snake which according to tradition was kept and domesticated by the natives as rat catchers in their homes. ${ }^{22}$ Thus, Cagsawa indicates "python's place", which is located at barangay Busay, northeast of Daraga, Albay (Fig. 5).

\footnotetext{
${ }^{17}$ Cavada y Vigo 1876: 222; Phivolcs-Albay.

18 Jagor 1875: 93.

${ }^{19}$ Cavada y Vigo 1876: 223.

${ }^{20}$ Medina 1893: 170; Perez 1901: 9, 12.

${ }^{21}$ Huerta 1865: 181; Platero 1880: 15, 22

${ }^{22}$ Reyes 1992: 207.
} 


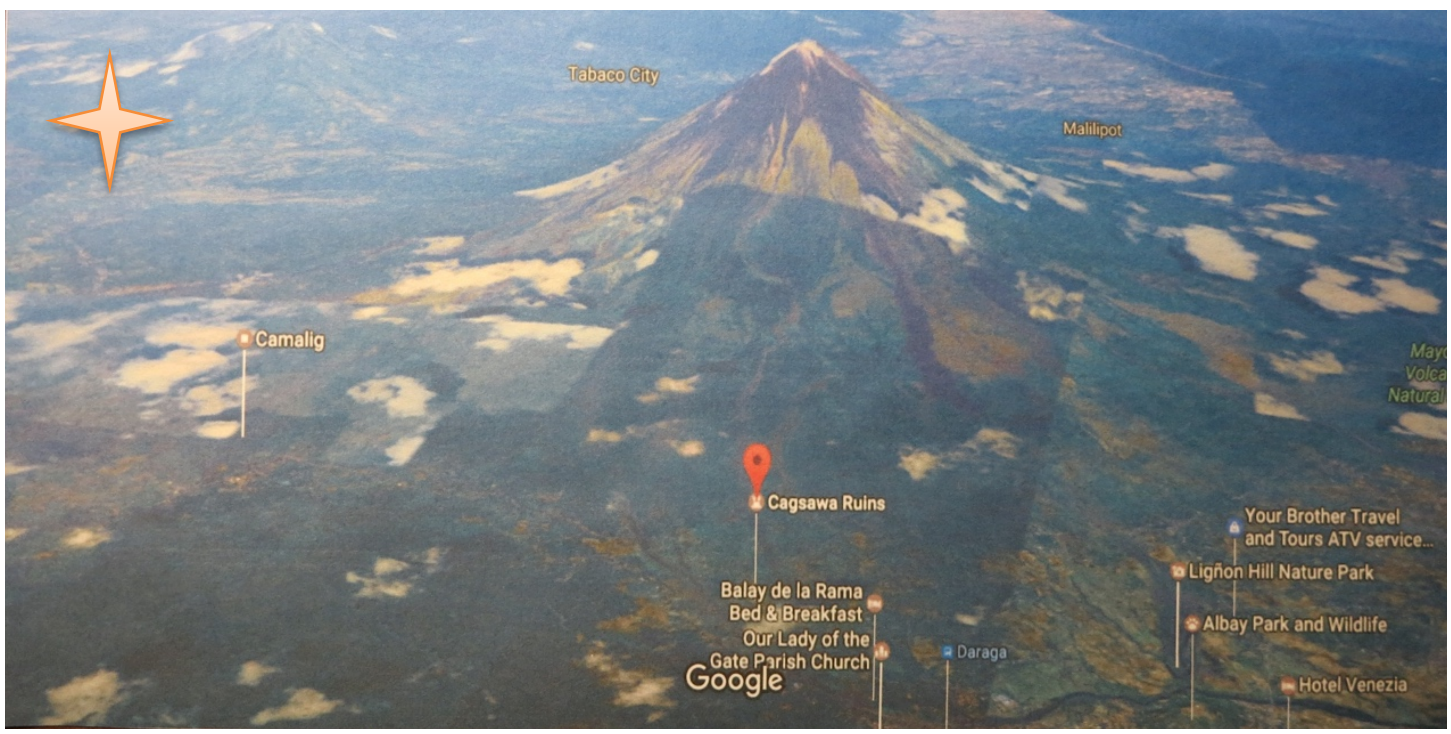

Fig. 5 Location of Cagsawa Ruins. Source: Google Earth.

When the Alcantarine Franciscans set foot in Cagsawa in 1587, they established a settlement of scattered native huts and began its reduccion and evangelization. The first Christian baptism took place in March of the same year to a twelve year old boy, Pedro Tabao, by Fray Pedro Bautista, OFM, who founded the mission in Cagsawa in $1591 .^{23}$ The church remained as a visita of Camalig under the patronage of San Juan Bautista de Camarines until 1605. During the festival celebration of the Parroquia de Cagsawa in honour of Saint James the Great on 25 July 1636, the Cagsaweños experienced major disaster when the Dutch battle fleets sailed into Philippine waters harassing the archipelago to wrest it from Spanish control. The Dutch raiders landed and sacked Albay town, proceeded to Cagsawa and set the defenceless pueblo on fire. Aside from human-made disasters, the Cagsaweños suffered from cyclic calamities brought by the regular monsoon typhoons and occasional volcanic mudslides, lava flows and floods. During the first foundation years of Christianity in Cagsawa, the church was made of wood that deteriorated later. In this case they would need lime and mortar to build their church and the limestone was available only in the littoral tidelands of Albay town but they needed to ask the Minister Provincial of the Franciscans to obtain permission from the Governor to freely gather limestone in the area.

The first stone church of Cagsawa was built by Fray Acacio de la Concepcion, OFM, in 1675 under the patronage of Saint James the Great. Later in 1724, the church was demolished by Fray Francisco Blanco, OFM, who rebuilt a bigger one including a convent of masonry on the same site. Added structures were belfry, court house (casa tribunal) made of planks with cemented stone, which served also as escuela de instruccion primaria or primary school, and four store rooms (almacines) of masonry.

\footnotetext{
${ }^{23}$ Huerta 1865: 269; Platero 1880: 55-56.
} 
On 1 February 1814, on the eve of the feast of Nuestra Señora de Candelaria, the most violent and destructive eruption of Mayon Volcano occurred. The distance of Cagsawa from the crater of Mount Mayon is about 10 kilometres away. This basalticandesitic stratovolcano produced thick, air fall, pumice deposits to generate pyroclastic flow that destroyed and devastated the nearby towns and villages in Albay, and ash from this eruption drifted and blew hundreds or thousands of miles away from the volcano. After the volcanic eruption, thousands of residents died in the towns of Camalig, Cagsawa, Budiao and Guinobatan. Besides the fury of the 1814 eruption which lay to waste these structures, the ruins that were left of them had been the mercy for the last 200 years. In the early 1930s the unburied, uppermost wall of the church façade was still intact (Fig. 6). Gradually, the remaining façade of the church toppled down perhaps due to earth tremors or strong typhoons since the façade had no buttresses to support it. In December 2015, the Cagsawa Ruins was declared as a National Cultural Treasure and Important Cultural Property by the National Museum of the Philippines.

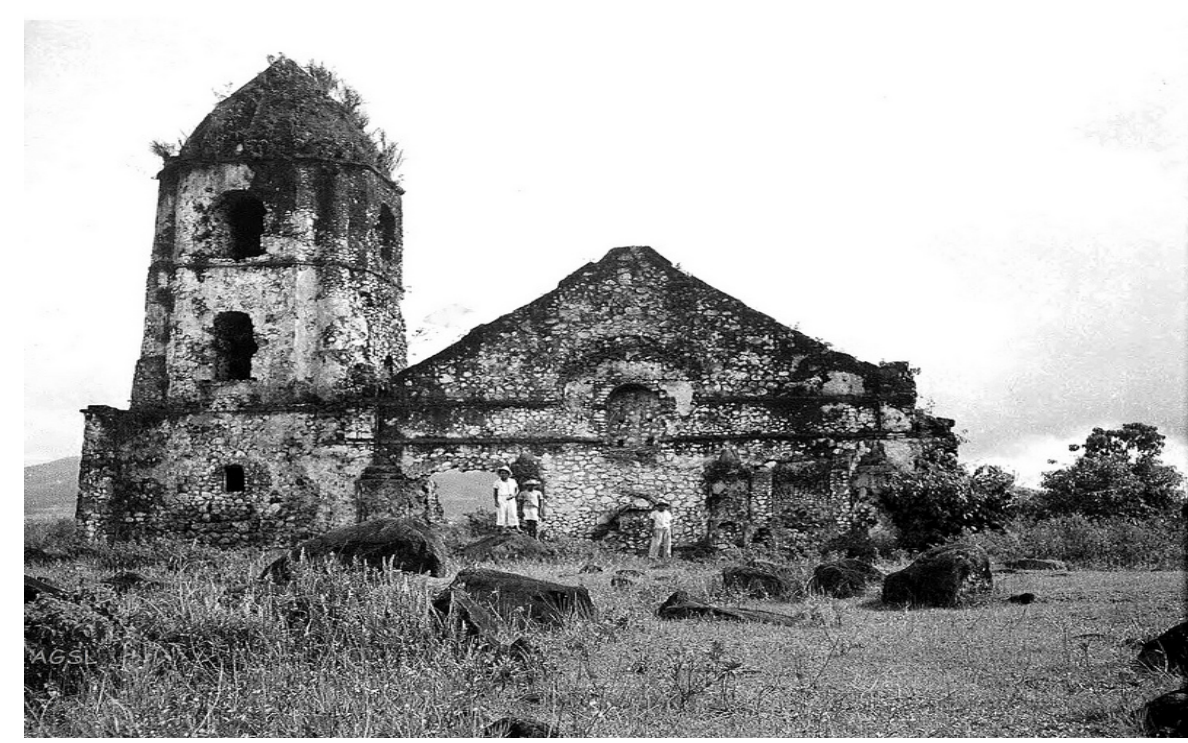

Fig. 6. Cagsawa Church, 1934. Source: John Tewell.

\section{Archaeological Significance}

The ruins in Cagsawa, Daraga, Albay, are an archaeological landmark, aside from being a historical marker, after the 1814 volcanic eruption of Mayon when numerous residents were allegedly killed and buried inside the church. Since then there were no archaeological endeavours to investigate the material remains. This research attempts to explore and survey the area which is considered as sacred spaces to determine the surviving and existing ruins in terms of structural design and religious function of the buildings based on the written accounts of the early Franciscan missionaries in Bicol Region. 


\section{Methods}

Three types of methods were used in this research: archival research, interview with the locals and surface exploration by using DIJ Phantom 3 Professional Quadcopter with $4 \mathrm{~K}$ camera drone. The archival research was conducted from January to October 2013 whilst the actual fieldworks were conducted on 30 December 2013, 28 December 2015, 26-29 April 2016, 17-19 October 2016 and 11-13 May 2017.

The Archivo Franciscano Filipino located at the Provincial House of the Order of Friars Minor in San Pedro Bautista in Quezon City contains primary source texts in relation to the early mission and evangelization of the Franciscans in Bicol. Most historical accounts were written in Spanish with Latin insertions. Other pertinent information was retrieved from private individuals like historians and collectors. Other data were provided by public archives and libraries.

Interviews with the locals, particularly the old folks in town, are very noteworthy since their relatives who had experienced the awful volcanic eruption of Mount Mayon had passed accounts to their children's children orally. The former parish priests of the Nueva Cagsawa (Daraga Church) had contributed significant information regarding the devastating catastrophes of Mount Mayon as experienced by their brother Franciscans who were assigned in the area. Other relevant data were supplied by some Albayanos that are living overseas.

The DJI Phantom 3 Professional Quadcopter with 4K camera drone was used to capture the entire aerial images of the ruins and its surrounding premises to disclose the material remains after the 1814 volcanic eruptions. Tape measure is applied to find out the dimension of every ruin and the distance from one ruin to another. Since the survey and study is preliminary, the use of Ground Penetration Radar (GPR) will be used later prior to excavation to determine the submerged structures. 


\section{Preliminary Findings}

During the survey and observation, there are no complete edifices except the belfry in which the lower tier or base is buried (Fig. 7). Though fragmented, each structure can

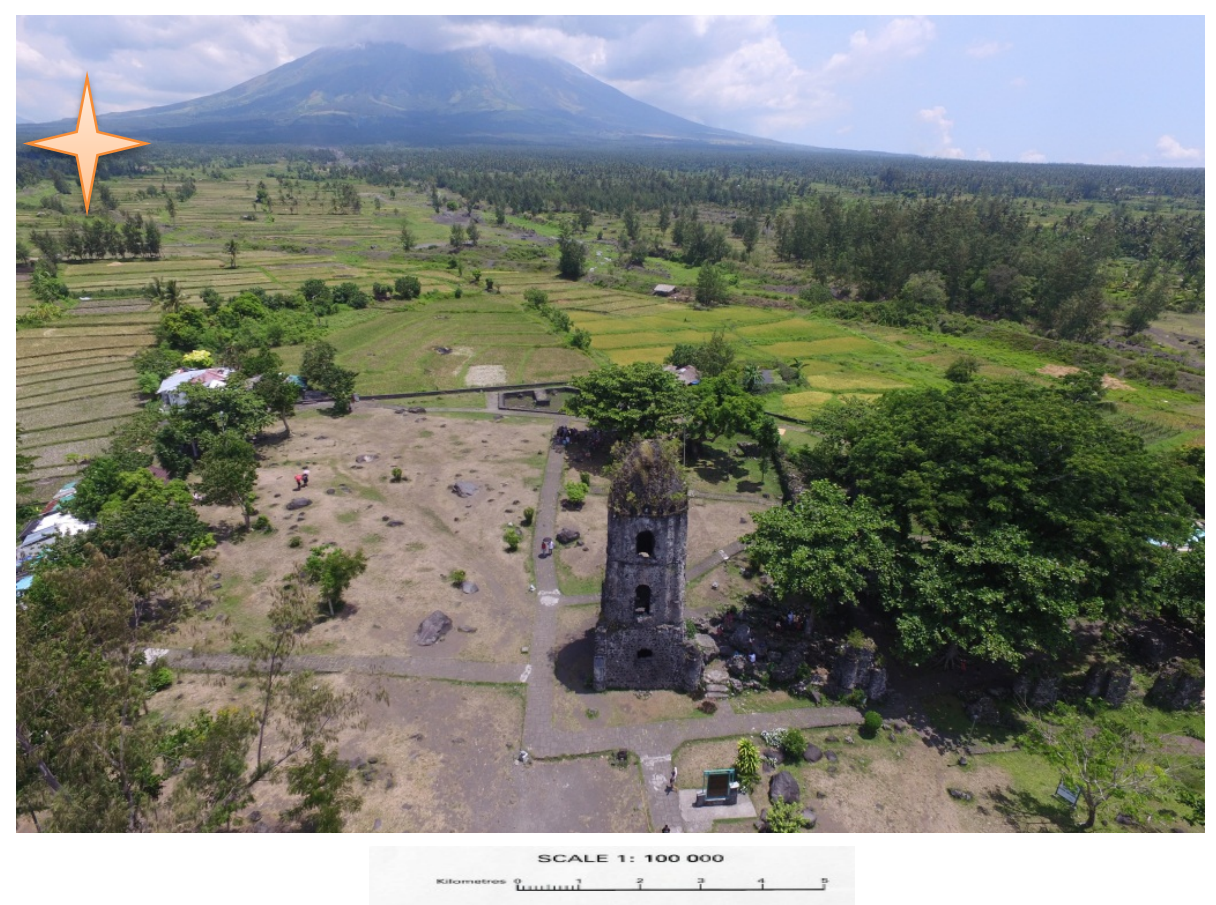

Fig. 7 Overview of the ruins in Cagsawa Source: Eva Recto.

be recognized and ascertained because some stone foundations and limits are intact in its respective position. Some parts of the ruins are covered by trees. Other parts, particularly on the southeast side, were torn down and cleared by the locals with the permission of the Local Government Unit (LGU) of Daraga, Albay to build resorts, establish ATV shops, convenient stores, souvenir shops, eateries and the like for tourists and guests. At present, the Cagsawa Park is managed by the municipal government of Daraga, Albay, in terms of entrance and parking fees in order to visit the ruins excluding hotel and swimming pool accommodations inside the premise.

\section{Franciscan missionary complex}

There are five different stone structures on the surface which are assigned from Structure A to E: Structure A, Belfry; Structure B, Church; Structure C, Convent; Structure D, Unidentified, and Structure E, Unidentified. The common layout of the construction of any Franciscan missionary complex in the Philippines includes church, convent, belfry and additional edifices for primary school or escuela de instruccion primaria, court house or casa tribunal, prison cells or carcel in some areas and royal house or casa reall.

${ }^{24}$ Huerta 1865: 258, 261, 266, 270, 274. 


\section{Structure A - Belfry}

The belfry or tore is a simple and four-sided pyramidal roof which is abrupt and stunted, capping a church tower. It has four tiers and formerly integrated into the church structure. The belfry is located at west direction when facing northward. In its present state, only three tiers of the belfry are observable because the fourth one is buried (Fig. 8 ). The lowest tier of the belfry has a different design from the two uppermost tiers that sit on it. The belfry's present base dimension is about 6.76 metres by 7.25 metres. The windows located at the base are almost covered by cement to prevent people from coming inside the tower for safety precaution. The upper part of the tier is surrounded by various species of plants native to the area, which grow in the crevices of basalt and andesite stones. The art of stone carving around the upper tier of the belfry is remarkable because it seems like a Mesoamerican design as it looks like a chief's headdress (Fig. 9). However, this stone carving design needs to be studied further.

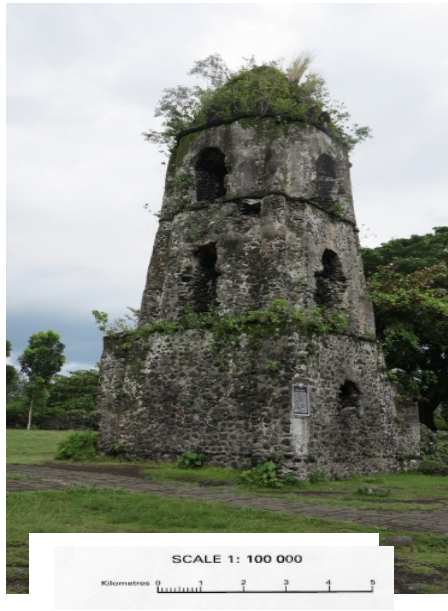

Fig. 8 Structure A, Belfry (Photo: AS Recto)
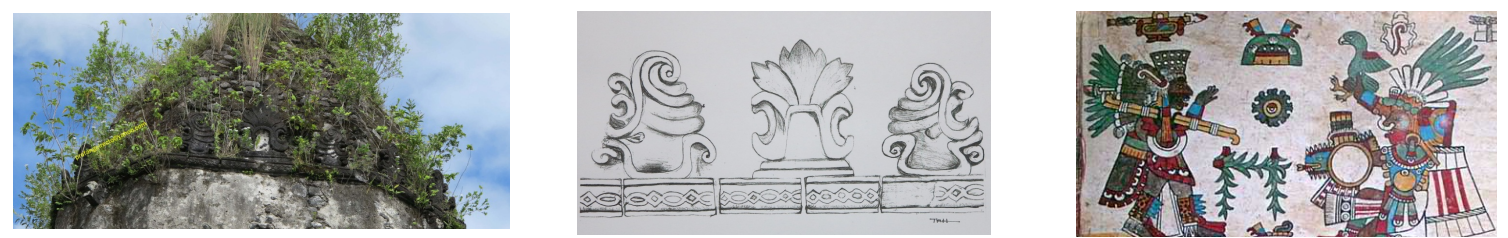

Fig. 9 L-R (stone carving at the uppermost tier of the belfry; sketched by JM Hipolito; Codex Borbonicus, 1899)

\section{Structure B - Church}

The church has a northeast orientation where the altar portion of the church is located to the north and the main entrance to the south. The southward (main entrance) to northward (altar) indicates that when the priest celebrated the Eucharist, he faces north towards the direction of Mount Mayon. There is no structural trace on the surface that the church has a transept, but it is a three-celled edifice (Fig.10). The end wall of the altar-side of the church is semi-circular in shape that served as the sacristy and chancel for the ministers and presider. ${ }^{25}$ The rectangular form of the church - the nave - has a dimension of about 43.7 metres in length by 23 metres in width. There are four rose windows on the semi-circular stone walls located at the east wing of the church that almost touch the ground. The sacristy, chancel and nave of the church are still visible and accessible, though dilapidated and covered by rubble stones. Some buttresses around the church and dilapidated walls can still be seen and touched. In other words, the only surviving structure of the church is dilapidated and fragmented walls in which more than half of the entire stone edifice seemed buried. The wall exterior is heavily covered by mosses, algae, and other microbiological organisms that inhabit the stone fissures.

25 Rodwell 1989: 67. 


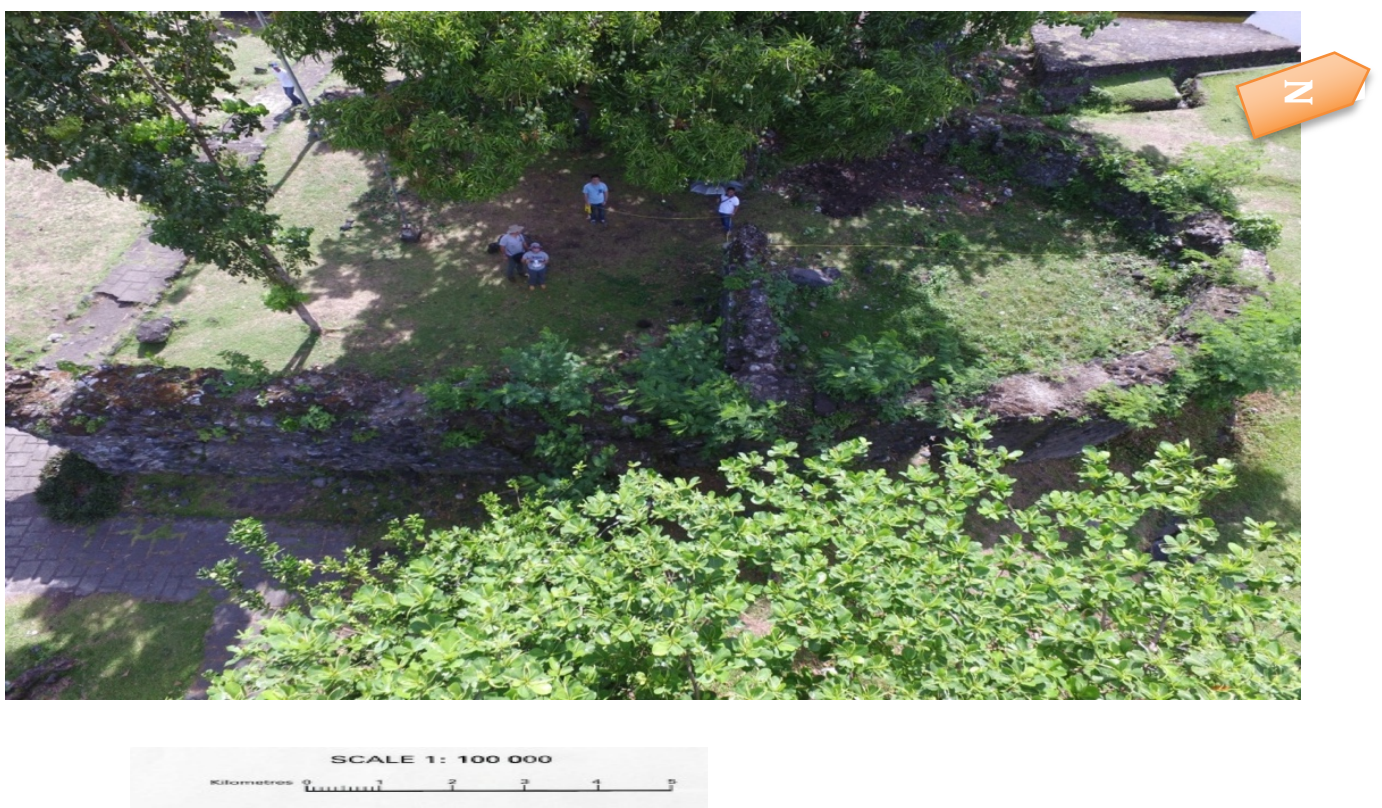

Fig. 10 Structure B, Church. Source: Eva Recto.

\section{Structure C - Convent}

The convent is also known as friary or casa parroquial where the Franciscan missionaries - both friars and clerics - dwelt. At present, the only material remains of the convent are dilapidated posts and broken walls that can hardly ascertain the exact location of the receiving area, refectory, kitchen, lavatories, oratory, dormitory, chapter sala, cells and space for penitential discipline in particular during the seasons of Advent and Lent and the passage of each. However, some windows with holes above the remaining stone walls - maybe for planks - are still visible amidst stone structure dilapidation (Fig. 11). Allegedly, the convent must have been a fairly large two-storey structure to probably accommodate the transient missionaries that passed the area or for spiritual exercises. ${ }^{26}$ Some parts of the ruins on the southeast direction are covered by thick vegetation where the tree roots are gradually tearing down the stone structure as time passes. Moreover, on the eastward direction, the adjacent stone structure connected to the convent was demolished because the Local Government Unit (LGU) of the town of Daraga, Albay, turned the space into a resort where they constructed hotel rooms, gazebos, conference halls and a swimming pool that are intended for visitors. There are some parcels of land around the ruins owned by private individuals that are used for business establishments.

\section{Structure D - Unidentified Structure}

The unidentified structure is located at the southeast direction of the Franciscan missionary compound. This stone dilapidated edifice is about 45 metres away from the belfry. The only visible material remains are the two pyramidal stone walls measuring about 9 metres in length facing each other. It gives the impression that the two pyramidal stone walls once served to support the roof. (Fig. 12) There is a trace

\footnotetext{
${ }^{26}$ Reyes 1992: 209.
} 
of stone structure on the surface (it looks as if buried) that connects the two pyramidal walls with each other. Trees and grass surround the area.
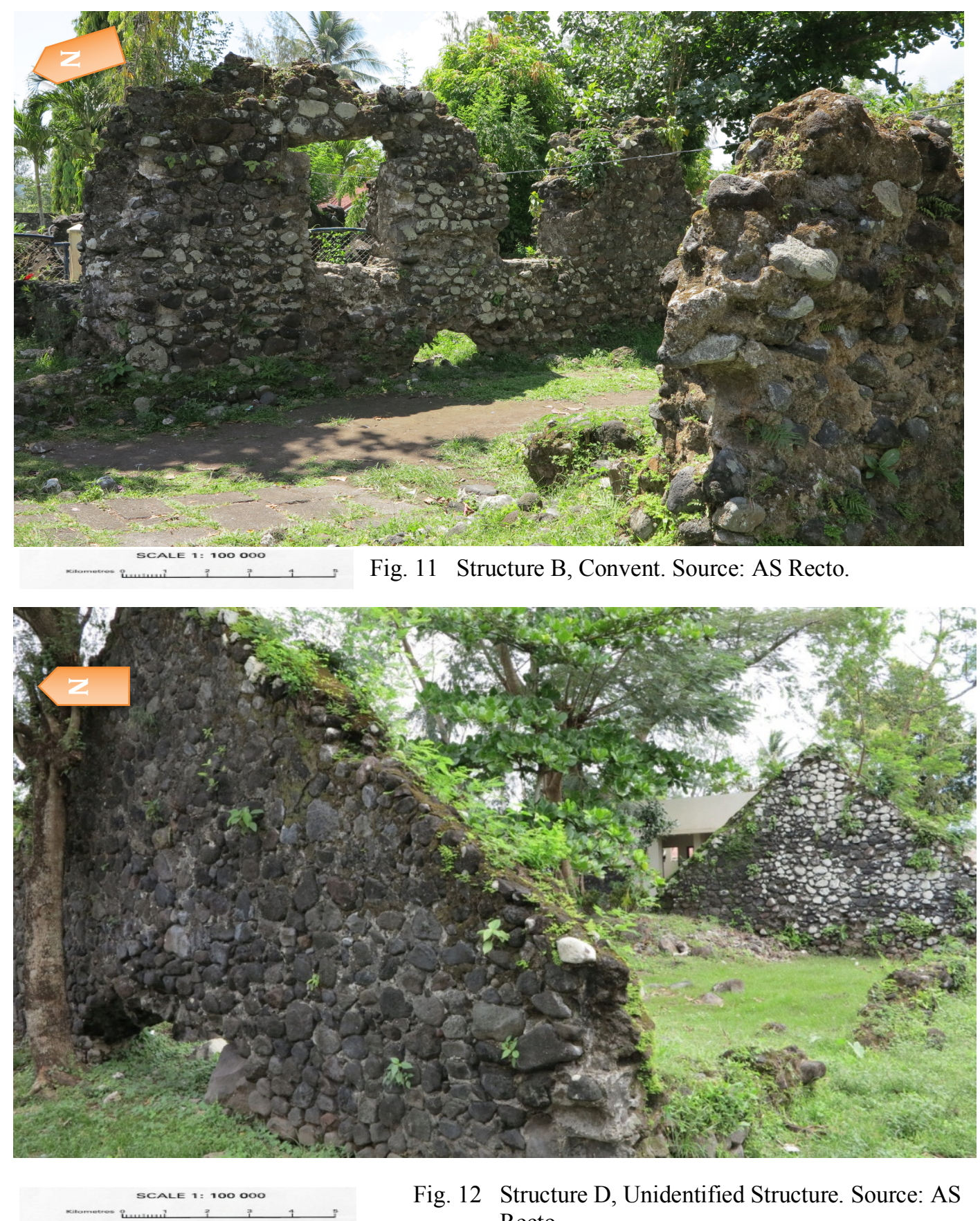

Fig. 12 Structure D, Unidentified Structure. Source: AS Recto.

\section{Structure E - Unidentified Structure}

Structure $\mathrm{E}$ is located northwest of the Franciscan missionary premise with a distance of around 200 metres from the belfry. Adjacent to this unidentified structure is the Busay River that runs from the east of Albay to the sea. The structure has dimensions of around 18 metres in width by 11 metres in length and it is quite difficult to determine the passage way of coming in and going out from the edifice by using the road or the river bank. The area is covered by thick vegetation aside from the two shanties (made of coco lumber and galvanized iron) built by the local tenants that 
have squatted at the place for several years (Fig. 13). Besides, there are holes from the four walls of the stone structure that give the impression of former supports for wooden beams and some dilapidated cubicles or rooms whose function cannot be identified. Some parts of the edifice seem buried.

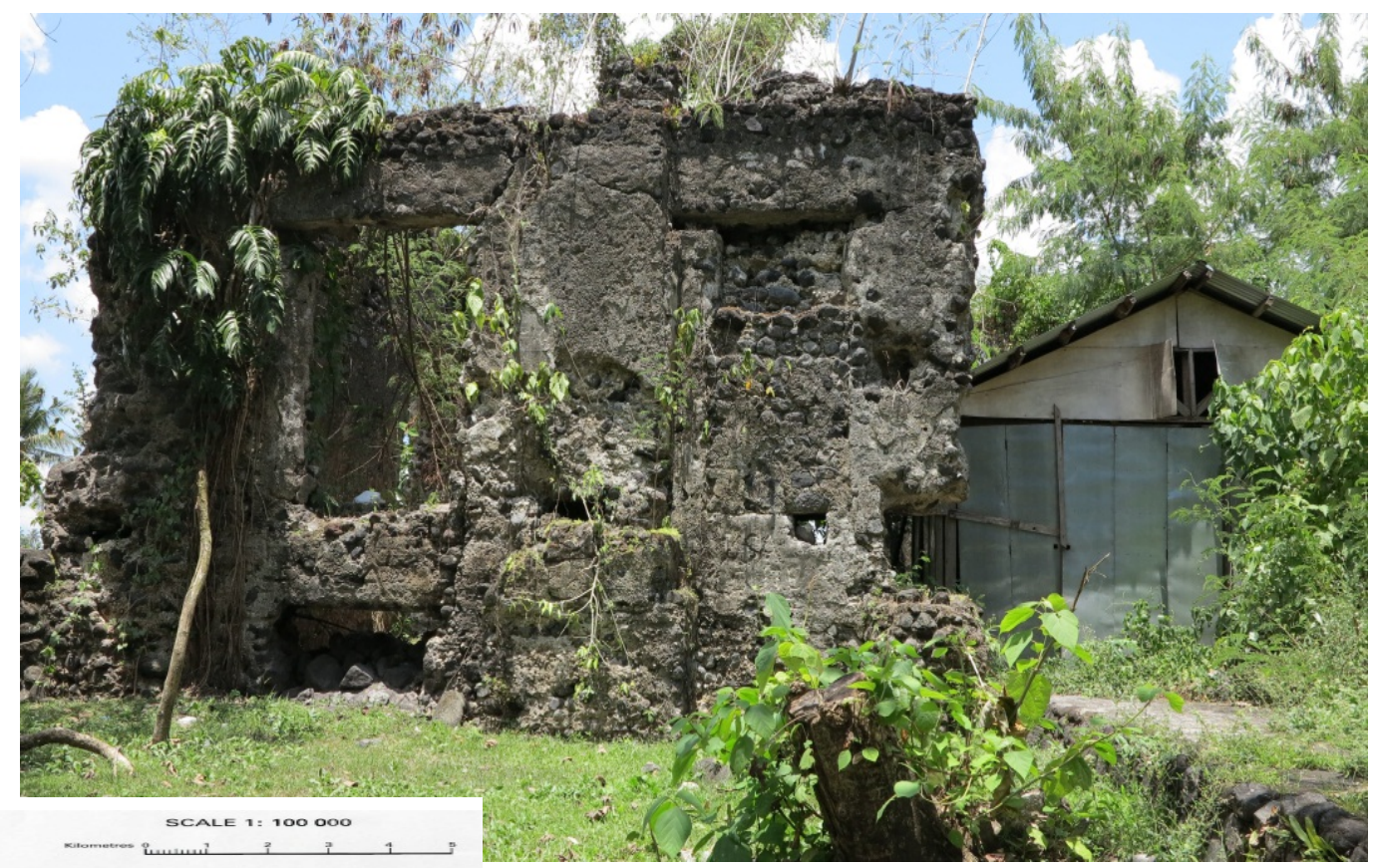

Fig. 13 Structure E, Unidentified Structure. Source: AS Recto.

\section{Map of the Franciscan Missionary Complex}

Since there is no existing map or blue print of the former Franciscan missionary complex of Cagsawa from the Archivo Francisco Filipino in Quezon City, the Philippines, and Archivo Franciscano Ibero-Oriental in Madrid, Spain, an attempt to lay out alternative map or blue print of the missionary compound of the Franciscans is inevitably by the help of DJI Phantom 3 Professional Quadcopter with $4 \mathrm{~K}$ camera drone and a 200-metre tape measure to get the entire image of the ruins and its premise. The map (Fig. 14) remains provisional for the time being since the output of this research is preliminary.

\section{Construction Technology}

The materials used in the construction of the Franciscan missionary buildings in Cagsawa are boulders of andesitic-basalt stone, which abound plentifully in the area. The building techniques that the friars applied in most churches in Bicol - particularly in Cagsawa and Budiao - is called mamposteria ${ }^{27}$ in which every stone is bonded by lime and mortar together with crushed and pulverized shells and broken pots as filler and support to the stone crevices (Fig. 15). The Franciscan builders used planks as beams and wrought iron as grills for the windows. In addition to this building technology are the stone carvings located at the uppermost tier of the belfry, which look like a Mesoamerican tribal chief headdress. Nevertheless in-depth study of that stone carving is necessary when archaeological excavation takes place.

\footnotetext{
${ }^{27}$ Huerta 1865: 271-271.
} 


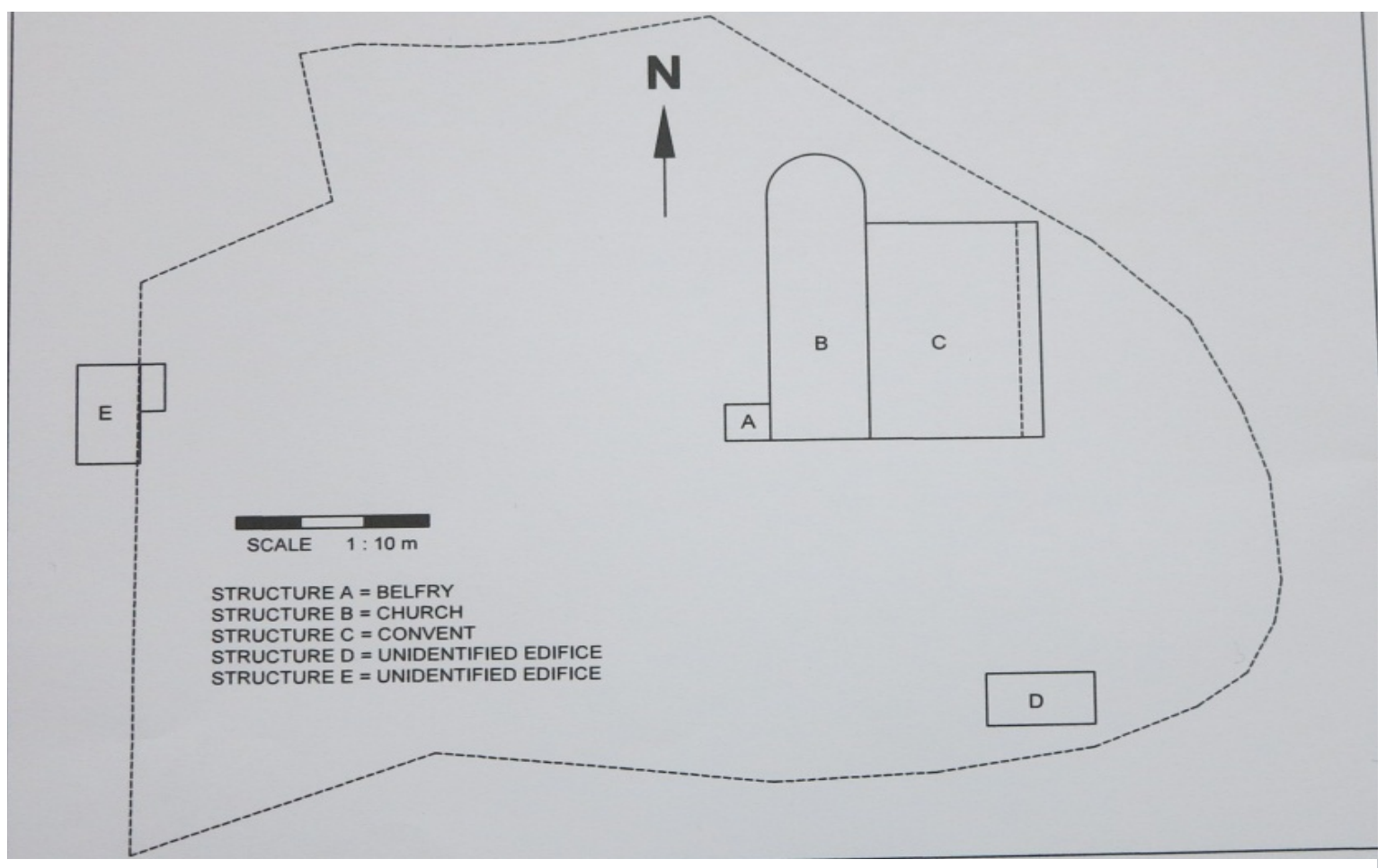

Fig. 14 Possible boundary (broken lines) of the former Franciscan Missionary Complex in Cagsawa, Albay (Sketched: RR Avellana)

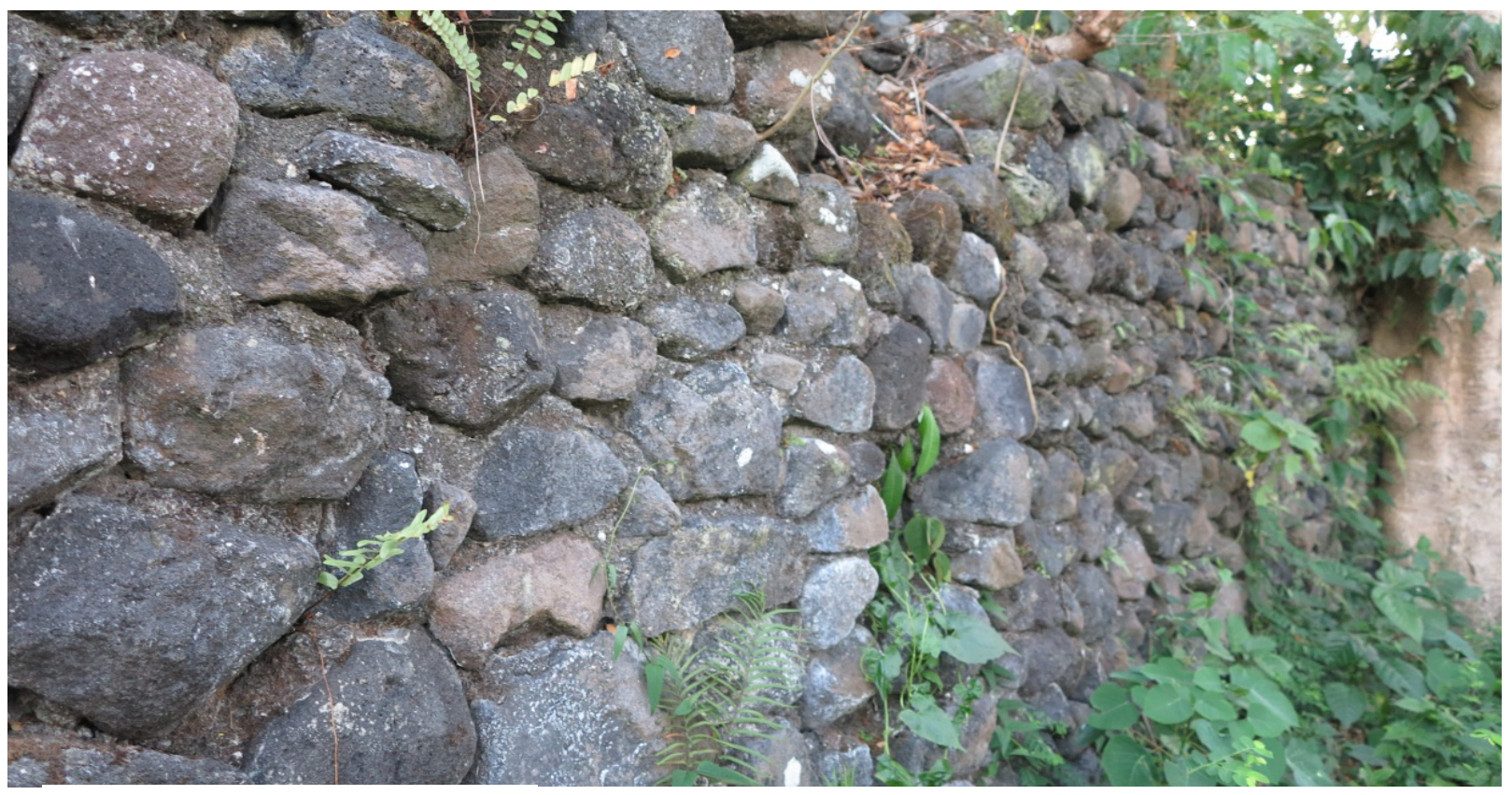

Figure 15. Mamposteria technology or stone masonry. Source: AS Recto)

\section{Discussion and Recommendations}

Based on the preliminary archaeological survey conducted in Cagsawa ruins, it seems that the entire dilapidated structures are composed of a huge complex of a former missionary centre of the Alcantarine Franciscans in the area since it was established more than two hundred years ago. It indicates that the area at the foot of Mount Mayon, where the early Franciscans established their mission, was highly populated. 
The Franciscan archivist confirmed that the Franciscan Order does not have any copy of the structural floor plan of the buildings of their mission in Cagsawa or even a map of the entire compound as reference because most of their documents were lost and destroyed during the 1898 departures of friars from the Philippines back to their Mother Province in Spain. What remains are only the works of early Franciscan missionaries who have mentioned their evangelization and temporal administration in the Bicol Region. Thus, the Order possesses no images or photos of what the former Franciscan missionary complex in Cagsawa looked like. Currently, there exist stone structures during the archaeological survey that need to be taken into account in order to make known the illustration of the entire area. Each dilapidated edifice was assigned as "Structure" to track it down easily for reference purposes: Structure A, Belfry; Structure B, Church; Structure C, Convent; Structures D and E are Unidentified. It is hard to pinpoint which among the two unidentified buildings is the primary school, or escuela de instruccion primaria, and/or the court house, or casa tribunal, since the two buildings exhibit only stone walls in which both have partly submerged. Moreover, adjacent to the convent were four almacenes ${ }^{28}$ or store rooms that during the survey could not be traced and recognized, at least on the surface. The plan of the area is based on the royal decree dictated by the kings to all colonized territories of Spain that each town should be situated on unoccupied elevated ground, properly oriented to the sun, wind and water areas. The place should be on or near the fertile land and accessible to sources of fuel, timber and water (in the case of Cagsawa and Budiao churches). The plaza was the starting point of the construction, around which are the important edifices like church, casa real, town hall, and other buildings for health and defence. Other spaces surrounding the area were reserved for merchant shops and prominent family dwellings.

It is further noticeable that some parts of the ruins were removed for aesthetics and tourism purposes under the supervision and management of the Local Government Unit (LGU) of the town of Daraga, Albay. The Diocese of Legazpi remains the guardian and caretaker of the ruins of Cagsawa. Souvenir shops and eateries outside and inside the ruins contribute noise, confusion and irresponsible garbage dumping around the area.

There are several hints and clues that the entire stone structures of A, B, C, D and E were buried, such as the bottom of the belfry's fourth tier under the ground; almost half of the entire edifice of the church is submerged; if the convent building has twostoreys then more than half of the entire structure is under the ground and the two unidentified stone structures located at the southeast and at the northwest are buried or at least around half of each structure. The walls that protect that entire complex could disclose the dimension of the total area through diggings. The dilapidated edifice of Structure E located at the north-west might be the key regarding the entrance and/or exit of those who were coming in and out from Cagsawa because the walls insinuate that there was no other passage for the people. In fact, the local government of Albay responsible for the entrance fees for visiting Cagsawa ruins improvised the present gate by cutting the walls and cementing the passage way for the people located at the southern part of the ruins.

\footnotetext{
${ }^{28}$ Huerta 1865: 270.
} 
In connection with these preliminary findings, archaeological excavations are highly recommended to better understand the entire material remains of the former Franciscan missionary complex in Cagsawa in terms of past cosmologies of the church orientation in reference to sacred worship and liturgy; stone structures with its binding materials; people walkways towards the church and convent; extent of depth of buried structures; and the like. It would be meritorious if the archaeological excavations start at the church sanctuary - the most sacred space - down to the aisle thru the main entrance and the dig should reach the flooring. The belfry would be the next but the dig should commence from the interior portion where the fourth tier is buried to avoid possible collapse if the diggings will start around the exterior portion of the tower. Regarding the convent, the excavation may start gradually from one of the passages that are connected to the sacristy down to the cubicles until the dig reaches the flooring of the building. It is better to first unearth Structure D located at the southeast direction to determine the extent of the edifice and its possible functions. Structure E located at the northwest should be excavated starting from the interior portion of the ruins on the northward facing Busay River to avoid collapse and further destruction. The application of Light Detection and Ranging (LIDAR) and Ground Penetrating Radar (GPR) prior to excavation would be very helpful in providing information on buried structural features in the site. Religious ritual in every endeavour should not be eradicated because the place to be excavated is a sacred space. Everything should be planned in accordance with the changing climate of the area and the volcanic activity of Mount Mayon.

\section{Acknowledgement}

This archaeological exploration - though preliminary - would never have happened without the help and support of the following agencies and individuals: the National Museum of the Philippines (Dr Eusebio "Bong” Dizon, Mr Angel P Bautista, Dr Mary Jane Louise A Bolunia); University of the Philippines-Archaeological Studies Program (Dr Armand Salvador Mijares, Dr Grace Barretto-Tesoro, Dr Victor Paz); Fray Reynaldo Legayada, OFM, archivist of Archivo Franciscano Filipino; Dr Danilo M. Gerona; Most Reverend Joel Z Baylon, DD Bishop of Legazpi; Arch. Ana M Lorilla; Dr Allan Gil Fernando; Ms Anna Margarita Tantoco; Arch. Roz Li of Bakas Pilipinas, Inc.; and Mr John Tewell.

\section{References}

Buzeta, M and Bravo, F (1850) Diccionario geografico, estadistico, historico de las Islas Filipinas. Madrid: Imprenta de D. Jose C. de la Peña. Google Scholar search.

Castaño, J (1895) Breve noticia acerca del origen, religion, creencias y supersticiones de los antiguos Indios del Bicol. Madrid. Google Scholar search.

Cavada, A and de Vigo, M (1876) Historia geografico, geológica y estadistico de Filipinas. Tomo Primero. Isla de Luzon. Manila: Imprenta de Ramirez y Giraudier. Google Scholar search.

Code of Canon Law (1983) Makati: St Paul Publishing. Google Scholar search. Crawfurd, J (1856) A Descriptive Dictionary of the Indian Islands and Adjacent Countries. London: Bradbury \& Evans. Crossref. 
De Rossi, GB (1864) La Roma Sotterranea Cristiana. Tomo Primero. Roma: Cromo Litografia Pontificia. Google Scholar search.

Eliade, M (1956) The Sacred and the Profane. New York: Harcourt, Brace \& World Inc. Google Scholar search.

Flannery, A (1975) Sacred Art and Sacred Furnishing in Sacrosanctum Concilium of the Second Vatican Council. New York: Costello Publishing Company. Google Scholar search.

Gorospe, V (1992) Banahaw: Conversation with a Pilgrim to the Power Mountain. Manila: Bookmark Inc. Google Scholar search.

Huerta, F (1865) Estado Geografico, topografico, estadistico, historico-religioso de la Santa y Apostolica Provincia de S. Gregorio Magno de Religiosos Menores Descalzos de la Regular e mas Estrecha Observancia de N.S.P.S. Francisco, en las Islas Filipinas. Binondo: Imprenta de M. Sanchez y Compania. Google Scholar search.

Isaac, E (1964) God's acre-property in land; a sacred origin? Landscape 14: 28-32. Google Scholar search.

Jagor, F (1875) Travels in the Philippines. London: Chapman \& Hall. Google Scholar search.

Jonova, J (2017) Heritage preservation and sacred art after the Second Vatican Council. Acta Universitatis Carolinae Theologica 7(1):193-206. Crossref.

Lanciano, R (1902) Storia degli scavi di Roma e notizie intorno le colezioni Romane di antichità. Volume Primo. Roma: Ermanno Loescher \& Co. Google Scholar search.

Maitland, C (1847) Church in the Catacombs: A Description of the Primitive Church of Rome. London: Longman, Brown, Green and Longmans Paternoster-Row. Google Scholar search.

Medina, J (1893) Historia de los successos de la Orden de N. Gran P.S. Agustin de estas Islas Filipinas. Manila: Tipo-Litografia de Chofre y Compania. Google Scholar search.

Meskell, L (2008) Memory's Materiality: Ancestral Presence, Commemorative Practice and Disjunctive Locales. In: RM Van Dyke and SE Alcock (eds) Archaeologies of Memory. Oxford: Blackwell Publishers, 35-55. Crossref.

Norman Habel, M (1991) Myth, Ritual and the Sacred. Underdale: University of South Australia. Google Scholar search.

Pius XI (1925) Motu Propio in Annuario Pontifico. Roma. Google Scholar search.

Park, CC (1994) Sacred Worlds: An Introduction to Geography and Religion. London: Routledge. Crossref.

Parker, JH (1877) The Archaeology of Rome: Catacombs. London: James Parker \& Co. Google Scholar search.

Perez, E (1901) Catalogo Bio-Bibliografico de los Religiosos Agustinos de la Provincia del Santisimo Nombre de Jesus. Manila: Establecimiento tipografico del Colegio de Sto. Tomas. Google Scholar search.

Pinelo, A d-L and Pereira J d-S. (1774). Recopilacion de Leyes de los Reynos de las Indias, Tomo Primero. Madrid. Google Scholar search.

Platero, EG (1880) Catalogo Biografico de los Religiosos Franciscanos de la Provincia de San Gregorio Magno de Filipinas. Manila: Imprenta del Real Colegio de Santo Tomas. Google Scholar search.

Reyes, JC (1992) Bikol Maharlika. Manila: Goodwill Trading. Google Scholar search. 
Rodwell, W (1989) Church Archaeology. London: B.T. Batsford Ltd/English Heritage. Google Scholar search.

Sanger, JP (1905) Censo de las Islas Filipinas. Tomo Primero. Madrid: Minuesa de los Rios. Google Scholar search.

Villamor, I (1920) Census of the Philippine Islands Vol. 1. Manila: Bureau of Printing. Google Scholar search.

Yengoyan, A.A (2006) Christianity and Austronesian Transformations: Church, Polity and Culture in the Philippines and the Pacific. In P Bellwood, JJ Fox and D Tryon (eds.) The Austronesians: Historical and Comparative Perspective. Canberra: ANU Press, 351-364. Google Scholar search. 